\title{
The first complete mitochondrial genome sequences for Ulidiidae and phylogenetic analysis of Diptera
}

kun xing ( $\square$ xingkun1215@126.com )

Shanxi Agricultural University

Chen Kang

Shannon Technology Group

Fei Zhao

Shanxi Agricultural University

\section{Research Article}

Keywords: Tetanops sintenisi, Diptera, Ulidiidae, mitochondrial genome, Diptera phylogenetics

Posted Date: March 7th, 2022

DOl: https://doi.org/10.21203/rs.3.rs-1406595/v1

License: (c) (1) This work is licensed under a Creative Commons Attribution 4.0 International License.

Read Full License 


\title{
The first complete mitochondrial genome sequences for Ulidiidae and phylogenetic analysis of Diptera
}

\author{
Kun Xing ${ }^{1 *}$, Chen Kang ${ }^{2 *}$, and Fei Zhao ${ }^{1, * *}$ \\ ${ }^{1}$ College of Plant Protection, Shanxi Agricultural University, Taiyuan 030031, China; xingkun1215@ 126.com (K.X.); \\ ${ }^{2}$ Shannon Technology Group, Taigu 0300800, China; kangchen6726@126.com (K.C.) \\ "These authors contributed equally to this work and should be considered co-first authors. \\ ${ }^{* *}$ Correspondence: zhaofei12@126.com; Tel.: +860351 713663
}

\begin{abstract}
Background: Tetanops sintenisi is a pest that mainly damages the roots of quinoa (Chenopodium quinoa) and it is first discovered in China in 2018. Methods and Results: Here, the complete mitochondrial genome (mitogenome) of $T$. sintenisi was sequenced and compared with the mitogenomes of other Diptera species. The results revealed that the mitogenome of $T$. sintenisi is 15763 bp in length (GenBank accession number: MT795181) and is comprised of 13 protein-coding genes (PCGs), 22 transfer RNA (tRNA) genes, 2 ribosomal RNA genes, and a non-coding A+T-rich region (959 bp). The highly conserved gene arrangement of the mitogenome of $T$. sintenisi was identical to that of other Diptera insects. Twelve PCGs contained the typical insect start codon ATN, while coxl had CGA as the start codon. The genes cox2, nad4, and nad1 contained an incomplete termination codon T; nad3, nad5, and cob contained the complete termination codon TAG; and the remaining seven PCGs contained the termination codon TAA. All tRNA genes were predicted to fold into the typical cloverleaf secondary structure. Phylogenetic analysis of 48 species based on the mitogenome sequence revealed that $T$. sintenisi clustered with the Tephritidae family, indicating that $T$. sintenisi and Tephritidae have a close phylogenetic relationship. Conclusions: The phylogenetic relationship of $T$. sintenisi based on the mitogenome was consistent with the traditional morphological taxonomy, according to which $T$. sintenisi belongs to the family Otitidae, which is closely related to the family Muscidae.
\end{abstract}

Keywords Tetanops sintenisi $\cdot$ Diptera $\cdot$ Ulidiidae $\cdot$ mitochondrial genome $\cdot$ Diptera phylogenetics

\section{Introduction}

Mitochondrion is an important organelle that exists in all eukaryotic cells. In addition to providing energy for cells, mitochondria are involved in processes such as cellular differentiation, messaging, and apoptosis, and they regulate cell growth and the cell cycle. Mitochondrial genome contains genetic information that is independent of nuclear genes, and it encodes the proteins, tRNAs, and rRNAs required by the mitochondria. The insect mitochondrial genome (mitogenome) is a circular double-stranded DNA molecule with a size of approximately 14-20 kb, consisting of 37 conservative genes, comprising 2 ribosomal RNA (lrRNA and srRNA), 22 tRNA, and 13 protein-coding genes (PCGs). It also contains a major non-coding region called mitochondrial DNA (mtDNA) A+T-rich region (or control region, $\mathrm{CR}$ ). Due to the simple structure, high copy number, relatively conserved gene arrangement, rapid gene evolution, and almost no recombination of the maternal genetic characteristics, insect mitochondria are currently widely used for the identification of insect species and determination of molecular phylogeny, biogeography, and genetic structure of the insect population.

To date, 255 insect mitogenome sequences representing 23 insect orders are available in the Insect Mitochondrial Genome Database (IMGD; http://www.imgd.org/). Among them, the number of sequenced mitogenomes of Diptera species is the highest, at 75 mitogenomes, accounting for $29.4 \%$ of the total [1], and it includes the mitogenomes of Helophilus virgatus [2], Hydrotaea dentipes [3], Delia antiqua [4], Bactrocera zonata [5], Bactrocera tsuneonis [6], Anopheles funestus [7], Ceratitis capitata [8], Cochliomyia hominivorax [9], Lucilia sericata [10], Chrysomya putoria [11], Mayetiola destructor [12], Stomoxys calcitrans [13], and Drosophila littoralis [14]. However, information on the Tetanops mitogenome is still limited. Therefore, further studies on the phylogeny and evolution of Diptera should be conducted to determine more relevant species sequences.

Tetanops sintenisi belongs to the family Ulidiidae of Diptera [15]. Its larvae mainly damage the roots of Chenopodium plants, causing the above ground parts to turn yellow and wilt and leading toa decreased growth and eventually death of the plants [16]. In recent years, this pest has broken out on quinoa (Chenopodium quinoa) fields in Shanxi Province in China, causing serious losses [16]. It was first captured from Calluna vulgaris in Bargerveen, central Holland in 1909 [15], and has been discovered in 
Ukraine, Finland, Latvia, Russia, and other regions in Eastern Europe [17]. Since 2000, it has been found in Poland, Germany, United Kingdom, and Belgium in Western Europe [18-21]. In China, it was first discovered in Jingle County, Shanxi Province in 2018 [16]. To our knowledge, the mitogenome of $T$. sintenisi or other species of the family Ulidiidae has not been previously determined.

Here, we characterized the mitogenome sequence of $T$. sintenisi and compared it with the mitogenome sequences of other insects, especially Diptera species. In addition, we used the mitogenome sequences to construct phylogenetic relationships among the 48 families of Diptera.

\section{Materials and Methods}

\section{Specimens}

On May 10, 2018, T. sintenisi larvae (approximately 50) were collected from a quinoa field $\left(112.2^{\circ} \mathrm{E}\right.$, $38.4^{\circ} \mathrm{N}$ ) in Jingle County, Shanxi Province, China. The samples were fixed in $99 \%$ anhydrous ethanol. The ethanol was replaced with fresh $99 \%$ anhydrous ethanol once after the samples were brought back to the laboratory, and the samples were stored in a refrigerator at $-30{ }^{\circ} \mathrm{C}$.

\section{Morphological characteristics}

The taxonomic status of quinoa root maggots was determined following the morphological identification characteristics reported in the literature [15]. The egg is $1 \mathrm{~mm}$ long, white or milky white, fusiform, slightly curved. The larva is $8-10 \mathrm{~mm}$ long, white, maggot-shaped, and the head is cone-shaped; the surface of the mature larva is tough, with a pair of spikes at the end of the tail section. The pupa is 7-9 mm long, cocoon-shaped, yellow at the beginning, and brown later. Adult body length is 6-9 mm, wingspan is 11-13 mm, and surface appearance is similar to housefly, with black, shiny body, without obvious stripes or bristles. The wings are transparent, and there is a brown streak at $1 / 3 \mathrm{rd}$ of the body of the subfront vein of the forewing (the identifying feature of this species). The end of the abdomen of the male fly is black and round, and the end of the abdomen of the female fly is dark to dark orange and pointed, with a long ovipositor at the end.

\section{Mitochondrial genome sequencing}

Ten larvae were selected and total DNA was extracted using a blood/cell/tissue genomic DNA extraction kit (Tiangen Biochemical Technology (Beijing) Co., Ltd.) according to the manufacturer's instructions. The concentration and purity of the total DNA were detected using a nucleic acid analyzer, and the integrity of the total DNA was evaluated through $1 \%$ agargel electrophoresis. After the quality test was completed, the DNA was sent to Shanghai Paisenol Biotechnology Co., Ltd. for sequencing. In this study, paired end (PE) sequencing was performed on these libraries using the Illumina MiSeq Sequencing platform and next generation sequencing (NGS).

\section{Sequence annotation and feature analysis}

A5-miseq V20150522 [22] and SPAdesv3.9.0 [23] were used to assemble high-quality second-generation sequencing data de novo and construct contig and scaffold sequences. The sequences were blasted (BLAST V2.2.31+) by comparing with the nt database in NCBI, and the mitochondrial sequences of each splicing result were selected.

Mitochondrial assembly results were integrated, and collinear analysis was performed using Mummer V3.1 [24] to determine the position relationship and fill the gap between contigs. Pilon V1.18 [25] was used to correct the results to obtain the final mitochondrial sequence. Then, we uploaded the complete mitogenome sequence to the MITOS (http://mitos.bioinf.uni-leipzig.de/) and MTannot (http://megasun.bch.umontreal.ca/cgi-bin/mfannot/mfannotInterface.pl) web servers for functional annotation [26]. All parameters were set to the defaults, except Genetic Code, which was set as 04-MOLD. The tRNA genes were identified and their potential secondary structures were inferred using MITOS online software. CGView visualization software was used to generate the whole genome circle map [27].

\section{Phylogenetic analysis}

We used 48 complete mitogenome sequences from Diptera and one Hymenoptera species as outgroups to construct phylogenetic relationships among families of Diptera. The nucleotide sequences of their complete mitogenome sequences were obtained from NCBI, and they were aligned using ClustalW in MEGA-X [28]. Maximum likelihood was used with Kimura 2-parameter model, and the number of 
repeated runs was set to 1000 to construct the phylogenetic tree. The Bayesian method was modeled as GTR+I+G, and MrBayes 3 software was used to run the system for 200,000 generations using a burn-in of $25 \%$ generations.

\section{Results}

\section{Mitochondrial genome structure}

The mitogenome of $T$. sintenisi was 15763 bp long (GenBank accession number ID: MT795181) and it consisted of 13 PCGs, 22 tRNA genes, 2 rRNA genes, and 1 non-coding control region. Minor coding strand encoded 23 genes, comprising 9 PCGs and 14 tRNA genes. The majority strand contained four PCGs, eight tRNA genes, and two rRNA genes (Figure 1 and Table 1). The annotated sequence has been deposited into GenBank under the accession number MT795181.

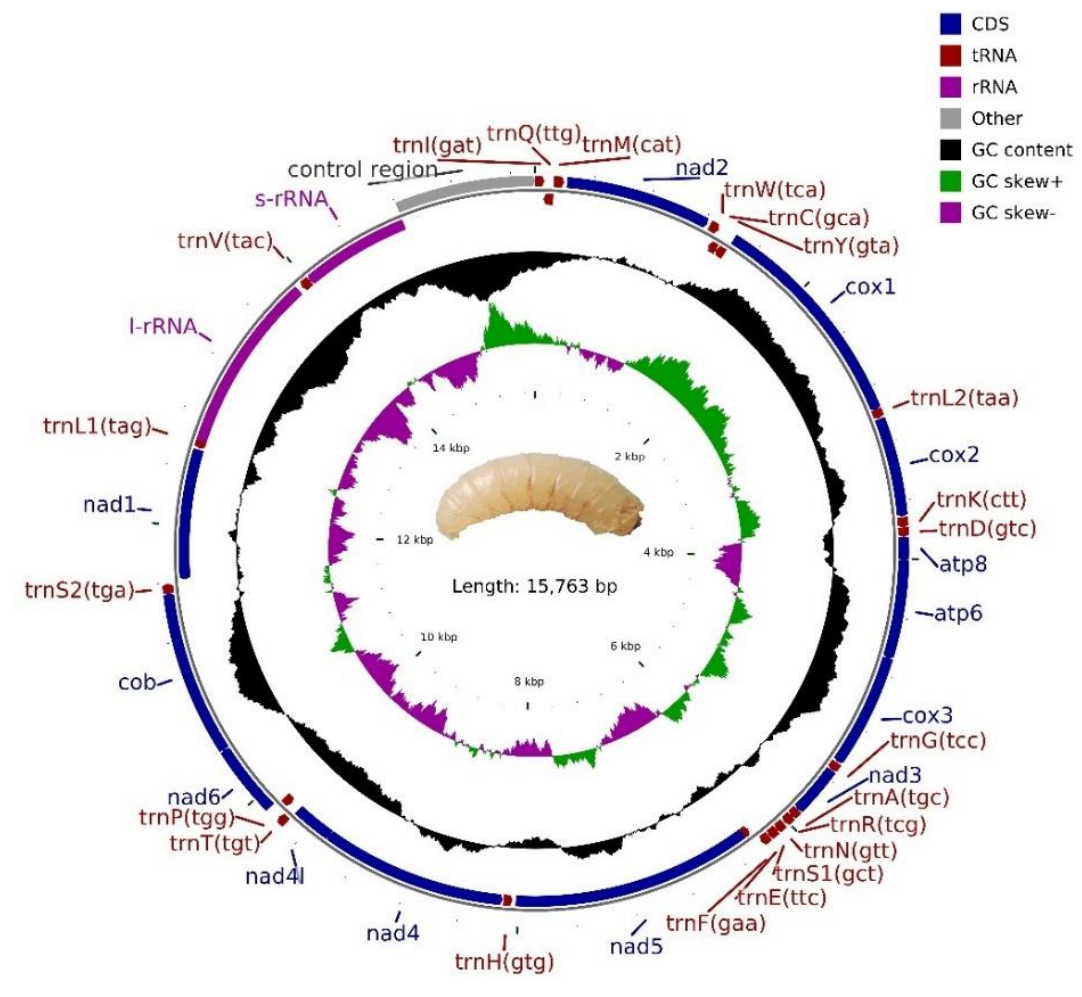

Fig. 1 Mitochondrial genome structure of Tetanops sintenisi. Genes outside the map are transcribed in a clockwise direction, whereas those inside the map are transcribed counterclockwise. The second circle shows the GC content and the third shows the GC skew.

Table 1. Organization of the mitochondrial genome of Tetanops sintenisi.

\begin{tabular}{cccccccc}
\hline Feature & Strand & Position & Length(bp) & $\begin{array}{c}\text { Start } \\
\text { codon }\end{array}$ & $\begin{array}{c}\text { Stop } \\
\text { codon }\end{array}$ & Anticodon & $\begin{array}{c}\text { Intergenic } \\
\text { nucleotide }\end{array}$ \\
\hline $\operatorname{trnI}$ & $\mathrm{N}$ & $1-64$ & 64 & & & $\mathrm{GAT}$ & -3 \\
$\operatorname{trn} Q$ & $\mathrm{~J}$ & $62-130$ & 69 & & & $\mathrm{TTG}$ & -1 \\
$\operatorname{trn} M$ & $\mathrm{~N}$ & $130-198$ & 69 & & & $\mathrm{CAT}$ & 21 \\
$n a d 2$ & $\mathrm{~N}$ & $220-1221$ & 1002 & ATT & TAA & & 18 \\
$\operatorname{trn} W$ & $\mathrm{~N}$ & $1240-1306$ & 67 & & & TCA & -8 \\
$\operatorname{trn} C$ & $\mathrm{~J}$ & $1299-1360$ & 62 & & & GCA & 1 \\
$\operatorname{trn} Y$ & $\mathrm{~J}$ & $1362-1426$ & 65 & & GTA & 1 \\
$\operatorname{cox} 1$ & $\mathrm{~N}$ & $1428-2963$ & 1536 & CGA & TAA & & -5 \\
$\operatorname{trn} L 2$ & $\mathrm{~N}$ & $2959-3023$ & 65 & & & TAA & 4 \\
$\operatorname{cox} 2$ & $\mathrm{~N}$ & $3028-3712$ & 685 & ATG & T(AA) & & 3 \\
$\operatorname{trn} K$ & $\mathrm{~N}$ & $3716-3786$ & 71 & & & CTT & -1 \\
$\operatorname{trn} D$ & $\mathrm{~N}$ & $3786-3852$ & 67 & & & GTC &
\end{tabular}




\begin{tabular}{|c|c|c|c|c|c|c|c|}
\hline atp 8 & $\mathrm{~N}$ & $3853-4014$ & 162 & ATC & TAA & & -7 \\
\hline atp6 & $\mathrm{N}$ & $4008-4685$ & 678 & ATG & TAA & & -1 \\
\hline $\cos 3$ & $\mathrm{~N}$ & $4685-5473$ & 789 & ATG & TAA & & 5 \\
\hline $\operatorname{trn} G$ & $\mathrm{~N}$ & $5479-5542$ & 64 & & & TCC & \\
\hline nad3 & $\mathrm{N}$ & $5543-5896$ & 354 & ATT & TAG & & -2 \\
\hline $\operatorname{trn} A$ & $\mathrm{~N}$ & $5895-5958$ & 64 & & & TGC & -1 \\
\hline $\operatorname{trnR}$ & $\mathrm{N}$ & $5958-6020$ & 63 & & & TCG & 8 \\
\hline $\operatorname{trn} N$ & $\mathrm{~N}$ & $6029-6093$ & 65 & & & GTT & \\
\hline $\operatorname{trnS1}$ & $\mathrm{N}$ & 6094-6161 & 68 & & & GCT & \\
\hline $\operatorname{trn} E$ & $\mathrm{~N}$ & $6162-6226$ & 65 & & & TTC & 18 \\
\hline $\operatorname{trnF}$ & $\mathrm{J}$ & $6245-6308$ & 64 & & & GAA & -20 \\
\hline nad5 & $\mathrm{J}$ & $6289-8019$ & 1731 & ATT & TAG & & 24 \\
\hline $\operatorname{trn} H$ & $\mathbf{J}$ & $8044-8107$ & 64 & & & GTG & 6 \\
\hline nad4 & $\mathrm{J}$ & 8114-9446 & 1333 & ATG & $\mathrm{T}(\mathrm{AA})$ & & -7 \\
\hline nad4l & $\mathbf{J}$ & $9440-9736$ & 297 & ATG & TAA & & 2 \\
\hline $\operatorname{trnT}$ & $\mathrm{N}$ & 9739-9802 & 64 & & & TGT & \\
\hline $\operatorname{trn} P$ & $\mathrm{~J}$ & 9803-9867 & 65 & & & TGG & 23 \\
\hline nad6 & $\mathrm{N}$ & 9891-10394 & 504 & ATT & TAA & & -1 \\
\hline$c o b$ & $\mathrm{~N}$ & $10394-11530$ & 1137 & ATG & TAG & & -2 \\
\hline $\operatorname{trnS2}$ & $\mathrm{N}$ & $11529-11595$ & 67 & & & TGA & 18 \\
\hline nadl & $\mathrm{J}$ & $11614-12550$ & 937 & ATA & $\mathrm{T}(\mathrm{AA})$ & & 10 \\
\hline $\operatorname{trnL1}$ & $\mathrm{J}$ & $12561-12625$ & 65 & & & TAG & -15 \\
\hline$r r n L$ & $\mathrm{~J}$ & $12611-13912$ & 1302 & & & & 32 \\
\hline $\operatorname{trn} V$ & $\mathrm{~J}$ & $13945-14016$ & 72 & & & TAC & -1 \\
\hline$r r n S$ & $\mathrm{~J}$ & $14016-14804$ & 789 & & & & 0 \\
\hline $\mathrm{OH}$ & $\mathrm{N}$ & $14805-15763$ & 959 & & & & 0 \\
\hline
\end{tabular}

Gene spacing or overlap was found in 37 genes of the whole mitogenome except the control region. There were 16 intergenic spacers, $194 \mathrm{bp}$ in total, among which the longest intergenic spacer was $32 \mathrm{bp}$ and located between $r r n L$ and $\operatorname{trnV}$. There were 15 gene overlaps, a total of $75 \mathrm{bp}$, and the longest overlap (20 bp) was between $\operatorname{trn} F$ and $n a d 5$ (Table 1). The number of gene spacer regions was larger than that of the overlap regions and most spacer regions were longer than the overlap regions (Figure 1, Table 1).

The nucleotide composition of the genome was A: $\mathrm{T}: \mathrm{C}: \mathrm{G}=38.2 \%: 31.0 \%: 19.5 \%: 11.3 \%$. The $\mathrm{A}+\mathrm{T}$ content of the whole genome was $69.2 \%$, higher than that of $\mathrm{G}+\mathrm{C}(30.8 \%)$, and the $\mathrm{A}+\mathrm{T}$ content of all protein-codingand rRNA genes in the genome was higher than the $\mathrm{G}+\mathrm{C}$ content (Table 2). There was a high $\mathrm{A}+\mathrm{T}$ content bias in the mitogenome sequence, and the highest $\mathrm{A}+\mathrm{T}$ content was detected in the control area $(80.6 \%)$, which was much higher than that in the whole sequence; this result was consistent with the characteristics of base nucleotide composition bias in the insect control area.

Table 2. Nucleotide composition of mitochondrial genome.

\begin{tabular}{ccccccccc}
\hline Region & $\mathbf{A \%}$ & $\mathbf{C \%}$ & $\mathbf{G \%}$ & $\mathbf{T \%}$ & $\mathbf{A + T} \%$ & $\mathbf{G + C \%}$ & AT skew & GC skew \\
\hline Whole genome & 38.2 & 19.5 & 11.3 & 31.0 & 69.2 & 30.8 & 0.103 & -0.267 \\
nad2 & 31.5 & 19.9 & 10.8 & 37.8 & 69.3 & 30.7 & -0.091 & -0.296 \\
cox1 & 28.3 & 22.3 & 17.0 & 32.4 & 60.7 & 39.3 & -0.069 & -0.132 \\
cox2 & 31.8 & 21.3 & 14.2 & 32.7 & 64.5 & 35.5 & -0.014 & -0.202 \\
atp8 & 38.9 & 17.3 & 6.8 & 37.0 & 75.9 & 24.1 & 0.024 & -0.436 \\
atp6 & 30.4 & 23.6 & 12.8 & 33.2 & 63.6 & 36.4 & -0.044 & -0.296 \\
cox3 & 28.8 & 24.3 & 16.2 & 30.7 & 59.5 & 40.5 & -0.032 & -0.200 \\
nad3 & 33.0 & 22.6 & 10.2 & 34.2 & 67.2 & 32.8 & -0.017 & -0.379 \\
nad5 & 24.7 & 10.8 & 20.1 & 44.4 & 69.1 & 30.9 & -0.286 & 0.301 \\
nad4 & 23.3 & 10.7 & 20.0 & 46.0 & 69.3 & 30.7 & -0.327 & 0.301 \\
nad4l & 25.9 & 8.7 & 17.2 & 48.2 & 74.1 & 25.9 & -0.300 & 0.325 \\
nad6 & 37.7 & 18.7 & 7.5 & 36.1 & 73.8 & 26.2 & 0.022 & -0.424 \\
cob & 31.3 & 23.8 & 14.1 & 30.8 & 62.1 & 37.9 & 0.008 & -0.258 \\
nad1 & 20.8 & 9.8 & 20.9 & 48.5 & 69.3 & 30.7 & -0.399 & 0.361 \\
rrnL & 33.3 & 7.1 & 15.1 & 44.5 & 77.8 & 22.2 & -0.144 & 0.359 \\
rrnS & 33.5 & 9.1 & 18.4 & 39.0 & 72.5 & 27.5 & -0.077 & 0.336 \\
OH & 42.7 & 12.1 & 7.3 & 37.9 & 80.6 & 19.4 & 0.061 & -0.247 \\
\hline
\end{tabular}

\section{Protein-coding genes}

The total sequence length of 13 PCGs was 11145 bp, among which the longest gene was nad5 (1731 
bp) and the shortest gene was atp 8 (162 bp), located in the J-strand and N-strand, respectively. The start codon of cox2, atp8, atp6, cox3, nad4, nad4l, and $\operatorname{cob}$ was typically ATG. The start codon of nad2, nad3, nad5, and nad6 was ATT, and those of the remaining genes coxl and nadl were CGA and ATA, respectively (Table 1). The stop codon of nad2, coxl, atp8, atp6, cox3, nad4l, and nad6 was TAA, while that of nad3, nad5, and cob was TAG. The cox2, nad4, and nadl had an incomplete stop codon T (AA). Among the 13 PCGs, only three genes (atp8, nad6, and cob) showed slight A-bias, ranging from 0.008 to 0.024. The rest of the PCGs were T-skewed. There were four genes with G-bias, namely, nad5, nad4, nad4l, and nadl, which ranged from 0.301 to 0.361. The remaining PCGs showed C-bias (Table 2). Compared with the mitogenomes of other related species in Diptera, the A+T content of the PCGs in $T$. sintenisi was the lowest at $66.3 \%$; the A+T content in four other related species was more than $70 \%$; and the highest A+T content was in allium fly (76.5\%) (Table 3).

Table 3. Mitochondrial genome comparison of five species in Diptera.

\begin{tabular}{|c|c|c|c|c|c|c|}
\hline \multicolumn{2}{|c|}{ Species } & $\begin{array}{l}\text { Tetanops } \\
\text { sintenisi }\end{array}$ & $\begin{array}{c}\text { Bactrocera } \\
\text { oleae }\end{array}$ & $\begin{array}{l}\text { Ceratitis } \\
\text { capitata }\end{array}$ & $\begin{array}{c}\text { Delia } \\
\text { antiqua }\end{array}$ & $\begin{array}{l}\text { Anopheles } \\
\text { funestus }\end{array}$ \\
\hline \multicolumn{2}{|c|}{ GeneBank accession number } & MT795181 & NC_005333.1 & NC_000857.1 & КT026595 & MF775371 \\
\hline \multirow{2}{*}{ Whole genome } & $\begin{array}{l}\text { Size } \\
\text { (bp) }\end{array}$ & 15763 & 15815 & 15980 & 16141 & 15403 \\
\hline & $\begin{array}{c}\mathrm{A}+\mathrm{T} \\
(\%)\end{array}$ & 69.2 & 72.6 & 77.5 & 87.5 & 78.4 \\
\hline \multirow{2}{*}{$\begin{array}{l}\text { Protein- coding } \\
\text { genes }\end{array}$} & $\begin{array}{l}\text { Size } \\
\text { (bp) }\end{array}$ & 11145 & 11189 & 11183 & 11188 & 11080 \\
\hline & $\begin{array}{c}\mathrm{A}+\mathrm{T} \\
(\%)\end{array}$ & 66.3 & 70.2 & 75.6 & 76.5 & 76.6 \\
\hline \multirow{2}{*}{$r r n L$} & $\begin{array}{l}\text { Size } \\
(\mathrm{bp}) \\
\end{array}$ & 1302 & 1323 & 1335 & 1330 & 1329 \\
\hline & $\begin{array}{c}\mathrm{A}+\mathrm{T} \\
(\%)\end{array}$ & 77.8 & 79.0 & 81.8 & 82.3 & 83.4 \\
\hline \multirow{2}{*}{$r r n S$} & $\begin{array}{l}\text { Size } \\
\text { (bp) }\end{array}$ & 789 & 793 & 788 & 784 & 791 \\
\hline & $\begin{array}{c}\mathrm{A}+\mathrm{T} \\
(\%)\end{array}$ & 72.5 & 74.0 & 77.7 & 78.3 & 80.1 \\
\hline \multirow{2}{*}{$\mathrm{A}+\mathrm{T}$-rich region } & $\begin{array}{l}\text { Size } \\
\text { (bp) }\end{array}$ & 959 & 949 & 1004 & 1266 & 570 \\
\hline & $\begin{array}{c}\mathrm{A}+\mathrm{T} \\
(\%)\end{array}$ & 80.6 & 86.9 & 91.1 & 93.7 & 94.1 \\
\hline
\end{tabular}

MEGA-X software was used to analyze the relative synonymous codon usage (RSCU) and distribution of 13 PCGs in the mitogenome of T. sintenisi and its four related species (Figures 2 and 3 ). Among the five Diptera species, the most frequently employed amino acid was Ser2. The loss of synonymous codons was observed in the PCGs of A. funestus, D. antiqua, and C. capitata. The CUC encoding Leu1 was lost in all the three species, the CGC codon encoding Arg and the CUG encoding Leu1 were lost in both A. funestus and D. antiqua, and the AGG encoding Ser1 was lost in both $A$. funestus and C. capitata. In addition, the CUG encoding Leu1 was lost in A. funestus and D. antiqua, and the CCG encoding Pro was lost in $C$. capitata. Based on these findings, it is evident that the lost codons always ended in $\mathrm{C}$ or $\mathrm{G}$. Although no loss of synonymous codons was found in $T$. sintenisi and Bactrocera oleae, the content of the above codons was very low (Figure 2). Additionally, it is evident from Figure 2 that the codons with high frequency mostly ended in A or U (the part shown in blue and green in the figure). Therefore, the use of synonymous codons confirmed the biased characteristics of $\mathrm{A}+\mathrm{T}$ content in insect mitogenome. The distribution trend of the relative synonymous codons of 13 PCGs in $T$. sintenisi and its four related species was approximately the same (Figure 3 ). Although the mitochondrial PCGs of these five Diptera species had a preference in codon usage, the difference in preference was not significant, indicating that the mitogenome of Diptera species had a certain degree of conservation in the evolutionary process. This could indirectly reflect that more closely related species have more similar pattern of codon use. 

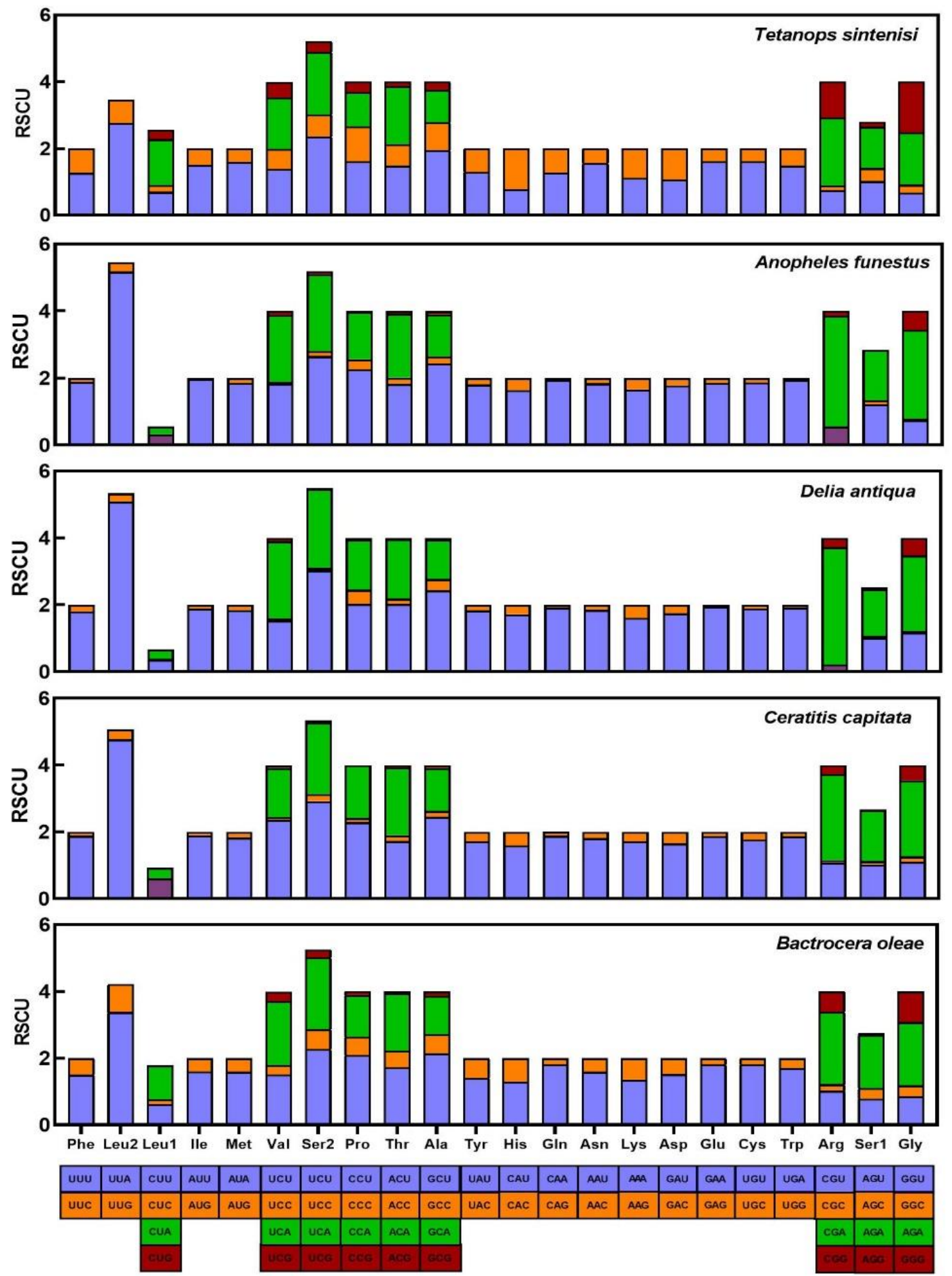

Fig. 2 The relative synonymous codon usage (RSCU) of the mitochondrial genome across five superfamilies in Diptera. 

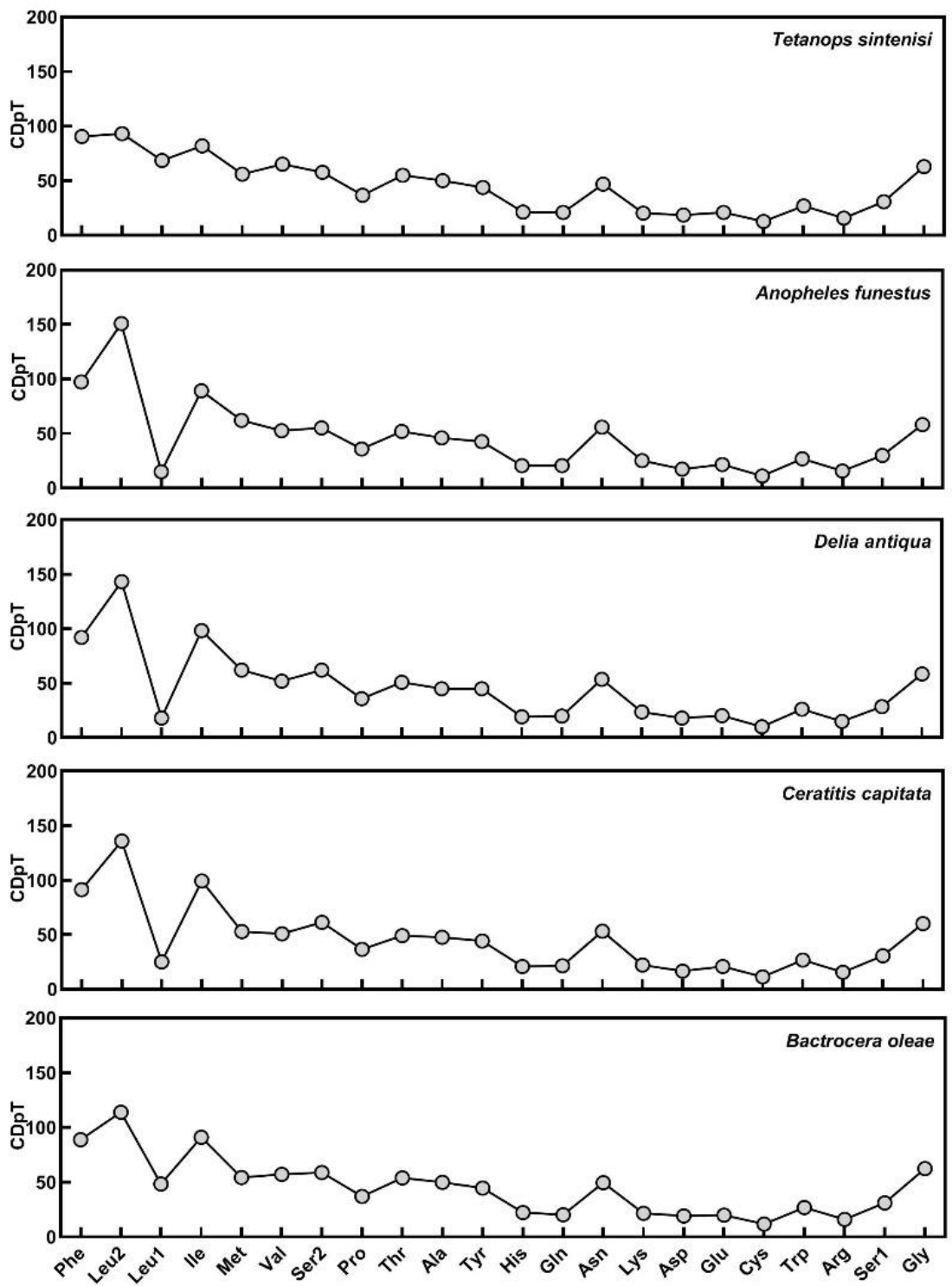

Fig. 3 Codon distribution in Diptera. CDpT, codons per thousand codons.

\section{Transfer RNA and ribosomal RNA genes}

The 22 tRNA genes of the mitogenome had a sequence length of 62-72 bp. $\operatorname{trn} C$ was the shortest tRNA gene with $62 \mathrm{bp}$, while $t r n V$ was the longest with $72 \mathrm{bp}$. Among the 22 tRNA genes, 14 tRNA genes were located in the N-strand and 8 tRNA genes were located in the J-strand. Twenty-three mismatched base pairs were identified in the tRNA genes, and these were all G-U pairs, comprising seven pairs located in the DHU arm of $\operatorname{trn} Q, \operatorname{trn} Y, \operatorname{trn} G(2), \operatorname{trn} H, \operatorname{trn} P$, and $\operatorname{trn} F$, nine pairs located in the acceptor stem of $\operatorname{trn} C$, $\operatorname{trn} Y, \operatorname{trn} S 1, \operatorname{trn} E, \operatorname{trn} H(2), \operatorname{trn} P, \operatorname{trn} F$, and $\operatorname{trn} A$, five pairs located in the anticodon arm of trnE, trnH, trnT, $\operatorname{trn} F$, and $\operatorname{trn} V$, and two pairs located in the T $\psi \mathrm{C}$ arm of $\operatorname{trn} P$ and $\operatorname{trn} F$ (Figure 4).

The two rRNA genes $r r n L$ and $r r n S$ were separated by $\operatorname{trn} V$. The length of the $r r n L$ sequence was $1302 \mathrm{bp}$, the intergenic spacer between $r r n L$ and $t r n V$ was $32 \mathrm{bp}$, and the A+T content was 77.8\%. The length of the $r r n S$ sequence was $789 \mathrm{bp}$, which overlapped with $\operatorname{trn} V$ by $1 \mathrm{bp}$, and the A+T content was $72.5 \%$ (Tables 1 and 2). The length of $r r n L$ of $T$. sintenisi was the shortest among the five relative species and its A+T content was the lowest. The length of $r r n S$ was the shortest in D.antiqua (784 bp), while the $r r n S$ of $T$. sintenisi was only five bases longer than that of $D$. antiqua, and the A+T content of $r r n S$ was still the lowest in $T$. sintenisi (Table 3). 
<smiles>O=C1CC(=O)CC(=CC2CCCC2)C1</smiles>

trnl<smiles>C#CC1CCCC(C2CCCC2)C1</smiles><smiles>C=CN=C1CC(=O)CC1=C</smiles>

trnA<smiles>C=C1CCC(C)C1</smiles><smiles>CC1CC(=O)CC(B2CCCC2)C1</smiles>

trnL1<smiles>C=CC1CC(=C2CCCC2)CC1=O</smiles>

$\operatorname{trn} Q$<smiles>CCCC1CCC(C(C)C)C1</smiles><smiles>CC1CC(C)C(C2CCCC2)C1</smiles>

trnR<smiles>C=CCC(=O)C1CCCCC1</smiles>

trnH

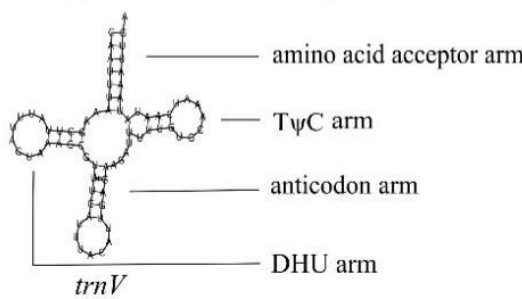

trnM<smiles>C1CCCC1</smiles><smiles>O=C1CC(C2CCCC2)CC(C2CCCC2)C1</smiles>

trnN<smiles>C=CC1CC(C)C(B2CCCC2)C1</smiles><smiles>CC(C)C1CCCCC1</smiles>

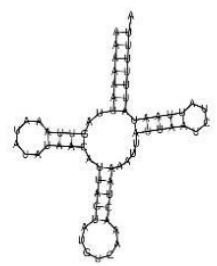

trnD

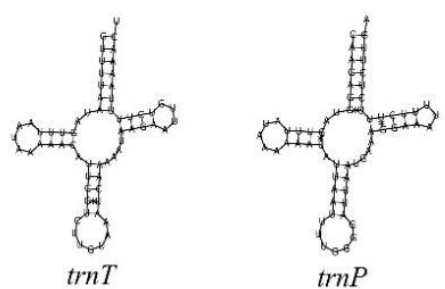

trnSI<smiles>C=C1CC(=C)C(=O)C1</smiles>

$\operatorname{trn} G$<smiles>[H][Z]1[CH]C(=C2CCCC2)CC(=C2CCC2)C1</smiles><smiles>C=C1CC(=C)C(C)C1</smiles>

trnE<smiles>C=C1CC(=C2CCCC2)CC1=C1CCCC1</smiles>

Fig. 4 Predicted secondary structure of tRNA genes in the mitochondrial genome of Tetanops sintenisi. The tRNAs are labeled with the abbreviations of their corresponding amino acids. Structural elements in tRNA arms and loops are illustrated as for trnV. Dashes (-) indicate Watson-Crick bonds and stars $\left(^{*}\right)$ indicate mistaken bonds.

\section{Control region}

The control region was the main non-coding region in the mitogenome sequence of $T$. sintenisi. The control region of $T$. sintenisi was $959 \mathrm{bp}$, located between $r r n S$ and $\operatorname{trnI}$, with the A, T, C, and G base contents of $42.7 \%, 37.9 \%, 12.1 \%$, and $7.3 \%$, respectively, and the A+T content of $80.6 \%$, thereby showing significant AT base bias (Tables 1 and 2). The control region included a total of nine (TA)n regions, of which five were $(\mathrm{TA})_{3}$, two were $(\mathrm{TA})_{4}$, one was (TA) $)_{5}$, and one was $(\mathrm{TA})_{6}$. Moreover, there were six poly-T regions with a length of $5 \mathrm{bp}$ or more, among which the longest was $17 \mathrm{bp}$. In addition, there were two repeat elements with a length of $13 \mathrm{bp}$ at $14868 \mathrm{bp}$ and $15037 \mathrm{bp}$, and an interval of 156 bp between the repeat elements. There were two repeat elements with a length of $17 \mathrm{bp}$ at $15305 \mathrm{bp}$ and $15357 \mathrm{bp}$, and an interval of $35 \mathrm{bp}$ between the repeat elements (Figure 5).

The control region length of these five related species ranged from $570 \mathrm{bp}$ to $1266 \mathrm{bp}$, with that of $T$. sintenisi being intermediate. The $\mathrm{A}+\mathrm{T}$ content in the control region ranged from $80.6 \%$ to $94.1 \%$, and the A+T content in $T$. sintenisi was the lowest (Table 3). 


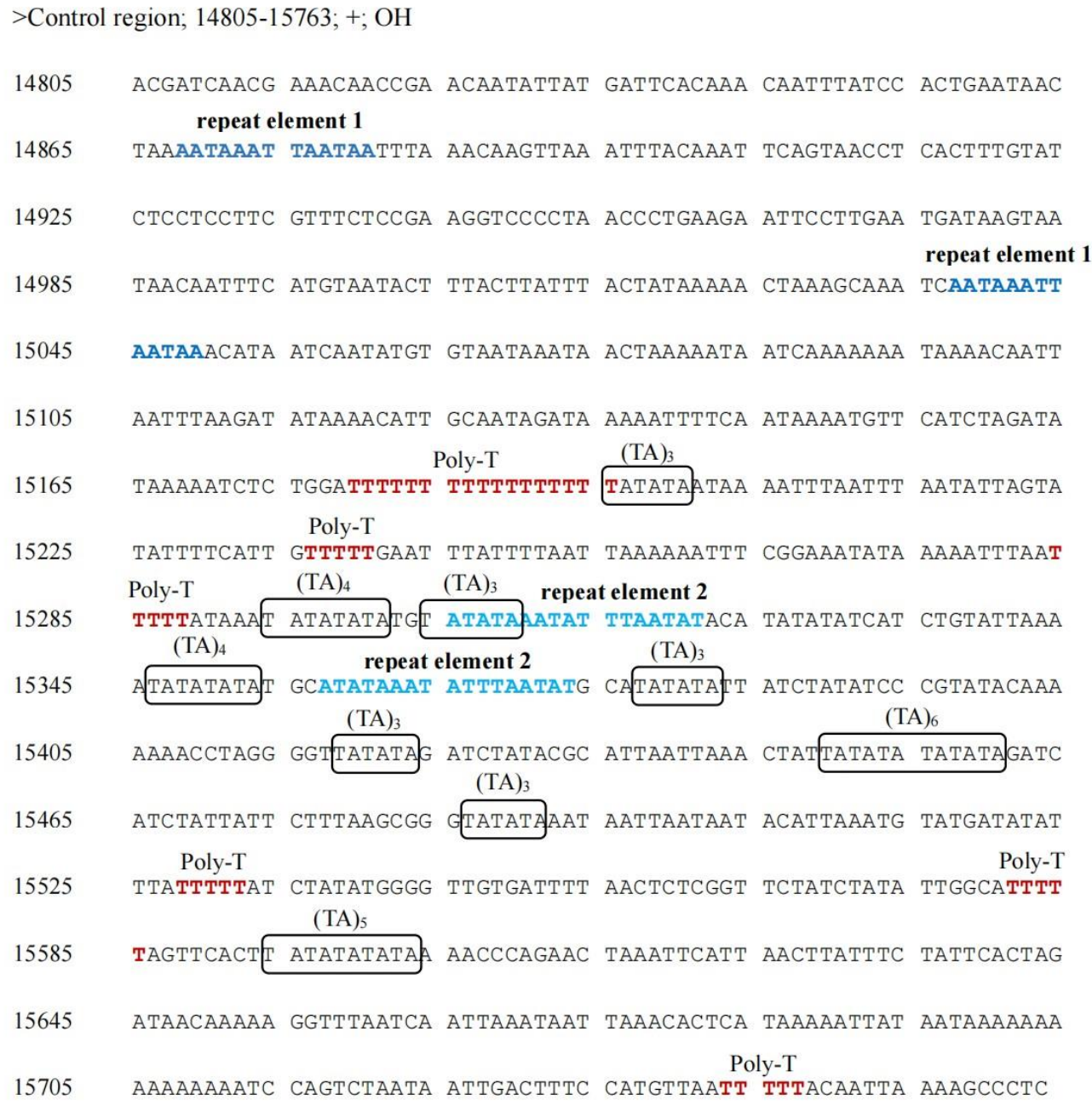

Fig. 5 Structure of the control region of the mitochondrial genome of Tetanops sintenisi. The (TA)nis marked with black box, the poly-T stretch is shown in red, and the repeat elements are shown in blue.

\section{Phylogenetic relationships}

In the traditional morphological classification, $T$. sintenisi is placed within Ulidiidae, but there are no reports on the complete mitogenome sequence of Ulidiidae species. Therefore, phylogenetic trees based on Maximum likelihood (ML) and Bayesian inference (BI) were constructed using complete mitogenome sequences of 48 species belonging to argonauts and other Diptera, with Apisdorsata (Hymenoptera) as the outgroup. The results showed that the topological structures of phylogenetic trees constructed with the two methods were basically the same, and the 48 Diptera species were grouped into three clusters (Aristocera, Nematocera, and Brachycera). Phylogenetic relationships were slightly different among the Aristocera. The phylogenetic relationship among Aristocera families constructed using ML method was: $((((($ Calliphoridae + Anthomyiidae $)+$ Muscidae $)+$ Drosophilidae $)+(T$. sintenisi + Tephritidae) $)+$ Agromyzidae $)+$ Syrphidae) (Figure 6), and that constructed using BI method was: $(((T$. sintenisi + Tephritidae $)+$ Drosophilidae $)+((($ Muscidae $+($ Calliphoridae + Anthomyiidae $))+$ Agromyzidae) + Syrphidae)) (Figure 6). However, in both the phylogenetic trees, Ulidiidae and Tephritidae were clustered together, indicating that the two families have a close relationship. 


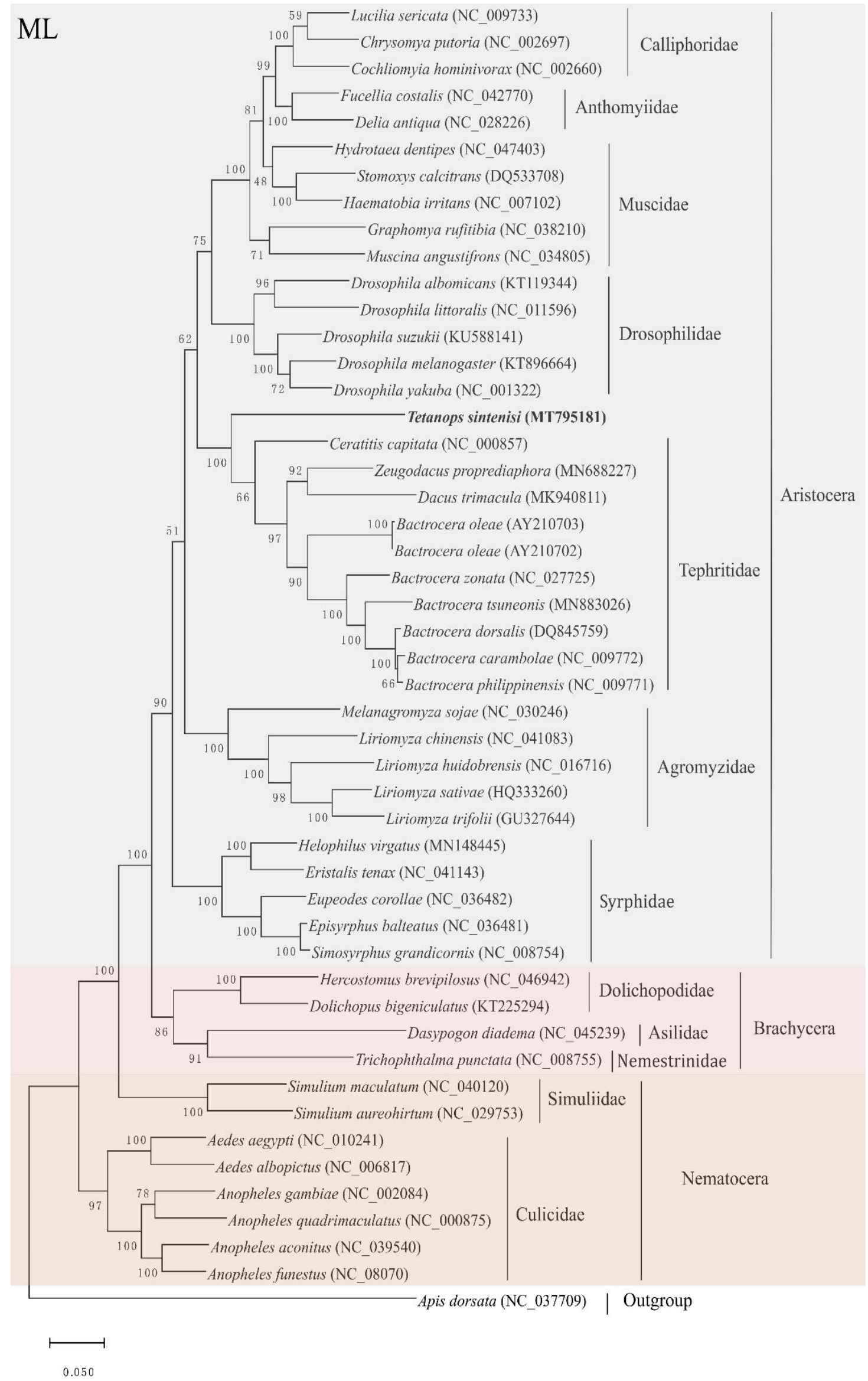




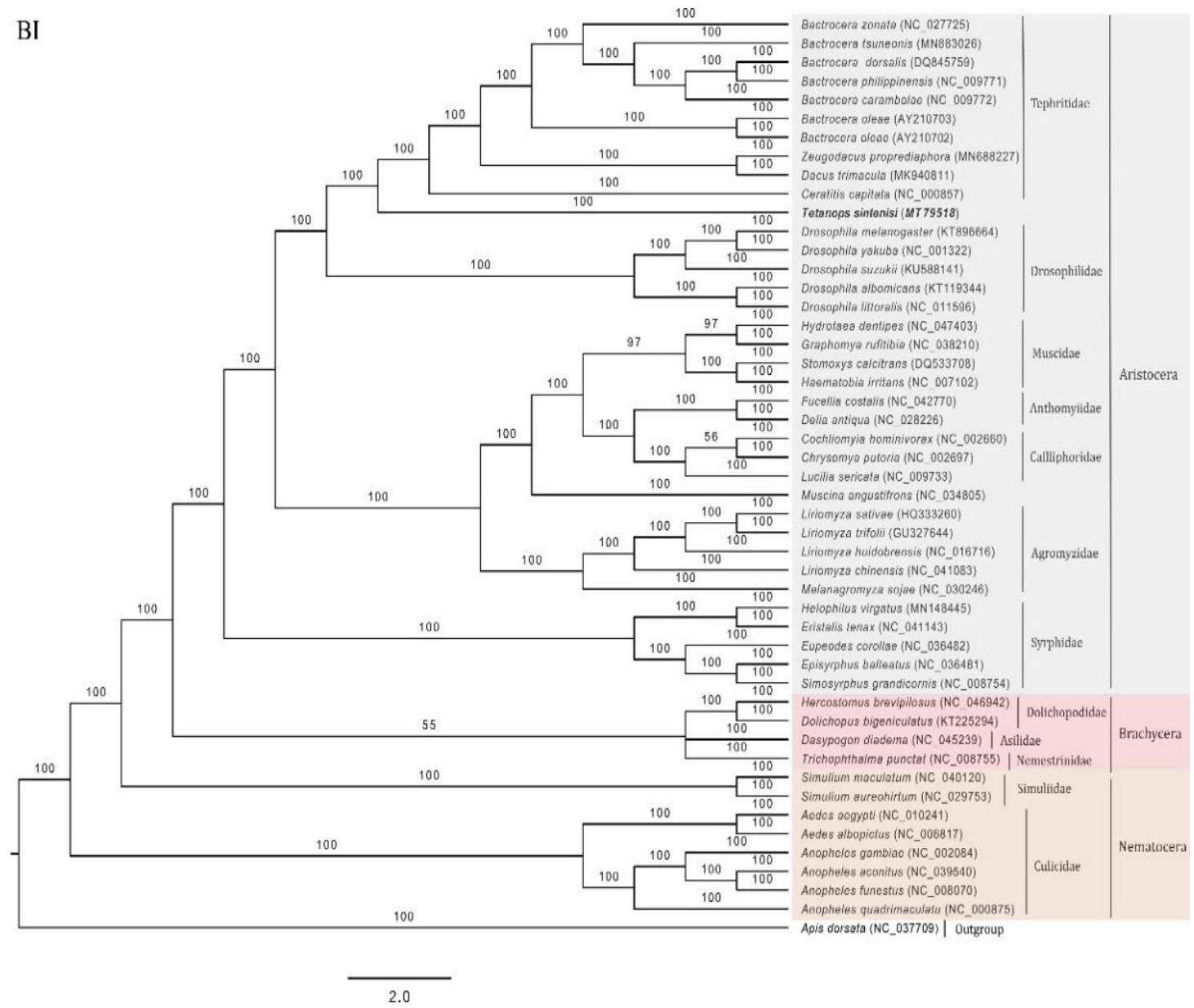

Fig. 6 Phylogenetic relationships of 48 Diptera, including Tetanops sintenisi, based on the whole-genome sequence data. The numbers beside the nodes are bootstrap values (maximum likelihood) and posterior probabilities (Bayesian inference), respectively.

\section{Discussion}

The mitogenome sequence of $T$. sintenisi was consistent with that of $D$. antiqua, D.melanogaster, and $B$. oleae, which are other known Diptera species [4, 29, 30], and exhibited the typical structure observed in Diptera. In evolution, rearrangement in the mitogenome of Diptera is relatively rare [4], which indicates the evolutionary conservatism of the mitogenome in Diptera. In the mitogenome of $T$. sintenisi, all the 12 PCGs contained the typical start codon ATN, but that of coxl was CGA (Table 1). The start codon of coxl is diverse in insects, it is a tetranucleotide (TTAG, ATAA, ATTA) [14, 31, 32], hexanucleotide (TATTAG, TTTTAG) [33], CGA [34], or TTG [35]. Although, it is commonly nearly identical among related insect groups, such as those of Lepidoptera [34] and Polyphaga [36], the present study found that start codon of coxl in T. sintenisi was not consistent with that in the known Diptera species (Table 4).

Table 4. Classification of the start codons of coxl.

\begin{tabular}{cccc}
\hline Type & Codon & Species & References \\
\hline Triplet & CGA & $\begin{array}{c}\text { Tetanops sintenisi } \\
\text { Limenitis helmanni } \\
\text { Rhyparochromidae } \\
\text { Haematobia irritans } \\
\text { Ttomoxy scalcitrans } \\
\text { Tetranucleotide }\end{array}$ & Wang et al., 2017[34] \\
& TCG & $\begin{array}{c}\text { Musca domestica } \\
\text { Bactrocera oleae }\end{array}$ & Oliveira et al., 2005[37] \\
& TTAG & $\begin{array}{c}\text { Coreana raphaelis } \\
\text { Drosophila yakuba }\end{array}$ & Nardi et al., 2003[30] \\
& ATTA & Drosophila melanogaster & Kim et al., 2006[32] \\
& & & De Bruijn, 1983[31]
\end{tabular}




\begin{tabular}{cccc} 
& ATCA & $\begin{array}{c}\text { Delia antiqua } \\
\text { Liriomyza sativae }\end{array}$ & $\begin{array}{c}\text { Zhang et al., 2015[4] } \\
\text { Yang et al., 2011[38] }\end{array}$ \\
\hline \multirow{3}{*}{ Hexanucleotide } & TATTAG & $\begin{array}{c}\text { Ostrinia nubilalis } \\
\text { Ostrinia furnicalis } \\
\text { Bombyx mori }\end{array}$ & Coates et al., 2005[33] \\
& TTTTAG & Coates et al., 2005[33] \\
\hline
\end{tabular}

The cox2, nad4, and nadl genes of T. sintenisi are terminated by a single T (Table 1). This partially coincides with other Diptera species (Table 5), suggesting that the usage of incomplete codons as stop codons is a common phenomenon in the Diptera $[11,14,39]$, and verifying the characteristics of $\mathrm{A}+\mathrm{T}$ content bias in the stop codon.

Table 5. Classification of the stop codons.

\begin{tabular}{|c|c|c|c|}
\hline Species & Codon & Genes & References \\
\hline Tetanops Sintenisi & $\mathrm{T}$ & $\operatorname{cox} 2, \operatorname{nad} 4$, nadl & \\
\hline \multirow[t]{2}{*}{ Bactrocera tsuneoni } & & & \multirow[t]{2}{*}{ Yue et al., 2018[40] } \\
\hline & TA & $\operatorname{cox} 1$ & \\
\hline \multirow{2}{*}{ Bactrocera zonata } & $\mathrm{T}$ & nad3, nad5, nad1 & \multirow{2}{*}{ Jaipal et al., 2015[5] } \\
\hline & TA & $\operatorname{cox} 1$ & \\
\hline Neoceratitis asiatica & $\mathrm{T}$ & nadl & Su et al., 2017[41] \\
\hline \multirow[b]{2}{*}{ Liriomyza sativae } & $\mathrm{T}$ & $\operatorname{nad} 2, C Y T B$ & \multirow[b]{2}{*}{ Yang et al., 2011[38] } \\
\hline & TA & nad5 & \\
\hline \multirow{2}{*}{ Delia antiqua } & $\mathrm{T}$ & $\operatorname{nad} 5, \operatorname{cox} 2$ & \multirow{2}{*}{ Zhang et al., 2015[4] } \\
\hline & TA & $\operatorname{nad} 4$ & \\
\hline
\end{tabular}

The location of the control region (A+T-rich region) in the mitogenome was relatively conserved but its length varied greatly from species to species. There were five common structures in the control region: a poly-thymidine stretch, a $[\mathrm{TA}(\mathrm{A})]_{\mathrm{n}}$-like stretch, a stem and loop structure, a $\mathrm{G}(\mathrm{A})_{\mathrm{n}} \mathrm{T}$ structure, and a G+A-rich sequence block [42]. In the present study, the length of the control region in T. sintenisi was $959 \mathrm{bp}$, and many (TA) $)_{\mathrm{n}}$ and poly-T structures were found in the control region. This was slightly different from that of some Diptera species, such as D. antiqua, whose control region is $1266 \mathrm{bp}$ and comprised of three tandem replicates, namely (TA) $)_{n}$, and poly-T, which were speculated to be involved in the control of transcription or replication [4]. The length of the control region in Liriomyza sativae is $741 \mathrm{bp}$, including poly-T and $\mathrm{G}(\mathrm{A})_{\mathrm{n}} \mathrm{T}$ structures [38]. This could be attributed to the difference in the number of copies of tandem repeatsin the control region between related species [42].This feature of high $\mathrm{A}+\mathrm{T}$ content and length difference in the control region is of great significance for the study of molecular evolution.

In the ML- and BI-based phylogenetic tree topologies, the 48 Diptera species were divided into three clusters, Aristocera, Nematocera, and Brachycera, and both topologies strongly supported the close relationship between $T$. sintenisi and Tephritidae (Figure 5). This result is consistent with the traditional morphological taxonomy. However, to date, the complete mitogenome sequences of Ulidiidae have been limited; therefore, further mitogenome sequencing and in-depth analyses of Ulidiidae and other families is required in future studies to determine a more comprehensive evolutionary relationship among the families of Aristocera.

To the best of our knowledge, this is the first report of the complete mitochondrial genome in the family Ulidiidae. Comparative analysis showed that the gene size, gene order, base content, and base composition are comparatively conserved, similar to other dipteran mitochondrial genomes. ATN is the initiation codon in all the 13 PCGs, except for $\operatorname{coxl}$, which starts with CGA. All tRNAs have the typical cloverleaf structure, and mismatched base pairs, all of which were G-U pairs, were identified in some tRNA genes. The location of the two rRNAs were conservative and the A+T content of the rRNAs was the lowest among the five related insect species. Two special structures were found in the control region, poly-T stretches and a (TA $)_{n}$ stretch, which are considered important elements related to replication and transcription. Both ML and BI analyses using nucleotide sequences of the whole mitogenome strongly suggest a closer relationship of $T$. sintenisi with Ulidiidae and Tephritidae. The whole mitogenome sequences have also been demonstrated as an effective method for resolving phylogenetic relationships [43]. The comparison of genomic features in related species should contribute to a comprehensive 
understanding of the evolutionary process of Diptera. The sequencing of the $T$. sintenisi mitogenome provides not only an important opportunity for ecological identification of Ulidiidae, but also valuable information for future evolutionary and molecular studies of Ulidiidae.

Acknowledgements We thank Wenna Wang for assistance in completing the experiments. This research was financially supported by the Foundation of Shanxi Academy of Agricultural Sciences (YCX2018D2T02) and the Province Key Research and Development Program of Shanxi (201903D221014).

Data availability statement The genome sequence data that support the findings of this study are openly available in GenBank of NCBI at https://www.ncbi.nlm.nih.gov/genbank under the accession no. MT795181. The associated BioProject, SRA, and Bio-Sample numbers are PRJNA757578, SRR15725549, and SAMN20968555, respectively.

Author contributions Conceptualization, K.X.; Formal analysis, K.X. and C.K.; Funding acquisition, F.Z.; Methodology, K.X and C.K.; Project administration, F.Z.; Writing-original draft, K.X. and C.K.; Writing-review and editing, F.Z. All authors have read and agreed to the published version of the manuscript.

\section{Compliance with ethical standards}

Conflict of interest The authors declare no conflict of interest. The funders had no role in the design of the study; in the collection, analyses, or interpretation of data; in the writing of the manuscript, or in the decision to publish the results.

\section{References}

1. Zhang NX, Zhang YJ, Guo YU, Chen B (2013) Structure characteristics of the mitochondrial genomes of Diptera and design and application of universal primers for their sequencing. Acta Entomol Sin 56(4): 398-407. https://doi.org/10.16380/j.kcxb.2013.04.013

2. $\mathrm{Li} \mathrm{H}, \mathrm{Li} \mathrm{J}$ (2019) The complete mitochondrial genome of Helophilus virgatus (Diptera: Syrphidae: Eristalinae) with a phylogenetic analysis of Syrphidae. Mitochondrial DNA Part B 4(2): 3106-3107. https://doi.org/10.1080/23802359.2019.1667890

3. Yan W, Shang Y, Ren L, Zhang X, Wang Y (2019) The complete mitochondrial genome of Hydrotaea dentipes (Diptera: Muscidae). Mitochondrial DNA Part B 4(1): 2044-2045. https://doi.org/10.1080/23802359.2019.1618217

4. Zhang NX, Guo Y, Li TJ, He QY, Zhou Y, Si FL, Shuang R, Chen B, Yue BS (2015) The complete mitochondrial genome of Delia antiqua and its implications in Dipteran Phylogenetics. PLoS ONE 10(10): e0139736. https://doi.org/10.1371/journal.pone.0139736

5. Choudhary JS, Naaz N, Prabhakar CS, Rao MS, Das B (2015) The mitochondrial genome of the peach fruit fly, Bactrocera zonata (Saunders) (Diptera: Tephritidae): complete DNA sequence, genome organization, and phylogenetic analysis with other tephritids using next generation DNA sequencing. Gene 569(2): 191-202. https://doi.org/10.1016/j.gene.2015.05.066

6. Wang T, Ren YL, Zhong Y, Yang MF (2020) Sequencing and analysis of the complete mitochondrial genome of Bactrocera cheni from China and its phylogenetic analysis. Mitochondrial DNA Part B 5(1): 780-781. https://doi.org/10.1080/23802359.2020.1715882

7. Mitchell SE, Cockburn AF, Seawright JA (1993) The mitochondrial genome of Anopheles quadrimaculatus species A: complete nucleotide sequence and gene organization. Genome 36(6): 1058-1073. https://doi.org/10.1139/g93-141

8. Spanos L, Koutroumbas G, Kotsyfakis M, Louis C (2010) The mitochondrial genome of the Mediterranean fruit fly, Ceratitis capitata. Insect Mol Biol 9(2): 139-144. https://doi.org/10.1046/j.1365-2583.2000.00165.x

9. Lessinger AC, Junqueira A, Lemos TA, Kemper EL, Azeredo-Espin A (2010) The mitochondrial genome of the primary screwworm fly Cochliomyia hominivorax (Diptera: Calliphoridae). Insect Mol Biol 9(5): 521-529. https://doi.org/10.1046/j.1365-2583.2000.00215.x 
10. Stevens JR, West H, Wall R (2010) Mitochondrial genomes of the sheep blowfly, Lucilia sericata, and the secondary blowfly, Chrysomya megacephala. Med Vet Entomol 22(1): 89-91. https://doi.org/10.1111/j.1365-2915.2008.00710.x

11. Junqueira A, Lessinger AC, Torres TT, Silva F, Espin A (2004) The mitochondrial genome of the blowfly $\begin{array}{lllll}\text { Chrysomya chloropyga } & \text { (Diptera }\end{array}$ https://doi.org/10.1016/j.gene.2004.06.031

12. Beckenbach AT, Joy JB (2009) Evolution of the mitochondrial genomes of Gall midges (Diptera: Cecidomyiidae): rearrangement and severe truncation of tRNA genes. Genome Biol Evol 1(1): 278-287. https://doi.org/10.1093/gbe/evp027

13. Oliveira MT, Barau JG, Junqueira A, Feijo PC, Lessinger AC (2008) Structure and evolution of the mitochondrial genomes of Haematobia irritans and Stomoxys calcitrans: the Muscidae (Diptera: Calyptratae) perspective. Mol Phylogenet Evol 48(3): 850-857. https://doi.org/10.1016/j.ympev.2008.05.022

14. Clary DO, Wolstenholme DR (1985) The mitochondrial DNA molecular of Drosophila yakuba: nucleotide sequence, gene organization, and genetic code. J Mol Evol 22(3): 252-271. https://doi.org/10.1007/BF02099755

15. Smit JT (2005) De prachtvlieg Tetanops sintenisi nieuw voor Nederland (Diptera: Ulidiidae). Nederlandse Faunistische Mededelingen 22: 91-94.

16. Xing K, Fei Z, Zhao X, Hui Y, Zhou J, Hong L (2018) First report of root maggot Tetanops sintenisi on quinoa. China Plant Protection 38(12): 38-40.

17. Mortelmans J, Bree ED, Hendrix J (2012) Four new additions to the Belgian fauna (Diptera: Conopidae, Tabanidae, Sciomyzidae, Ulidiidae). Bulletin van de Koninklijke Belgische vereniging voor entomologie 148: 193-196.

18. Stuke JH, Merz B (2005) Drei für Deutschland neu nachgewiesene acalyptrate Fliegen (Diptera: Lauxaniidae, Pallopteridae, Ulidiidae). Studia Dipterologica 12: 242-254.

19. Stuke JH (2006) Bemerkenswerte Zweiflügler aus Niedersachsen und Bremen (Insecta: Diptera) - 1. Teil. Drosera 12: 67-72.

20. Stuke JH (2008) Die Tephritoidea (Diptera) Niedersachsens und Bremens. Abh. Naturwiss. Vereins Bremen 46(2): 329-356.

21. John TS, Gerrit T (2014) Een bijzondere vangst van een bijzondere prachtvlieg (Diptera, Ulidiidae). Entomologische Berichten 74(6): 261-263.

22. Coil D, Jospin G, Darling AE (2014) A5-miseq: an updated pipeline to assemble microbial genomes from Illumina MiSeq data. Bioinformatics 31(4): 587-589. https://doi.org/10.1093/bioinformatics/btu661

23. Bankevich A, Nurk S, Antipov D, Gurevich AA, Dvorkin M, Kulikov AS, Lesin VM, Nikolenko SI, Pham S, Prjibelski AD (2012) SPAdes: a new genome assembly algorithm and its applications to single-cell sequencing. J Comput Biol 19(5): 455-477. https://doi.org/10.1089/cmb.2012.0021

24. Kurtz S, Phillippy A, Delcher AL, Smoot M (2004) Versatile and open software for comparing large genomes. Genome Biol 5(2): R12. https://doi.org/10.1186/gb-2004-5-2-r12

25. Walker BJ, Abeel T, Shea T, Priest M, Earl AM (2014) Pilon: an integrated tool for comprehensive microbial variant detection and genome assembly improvement. PLoS ONE 9(11): e112963. https://doi.org/10.1371/journal.pone.0112963

26. Bernt M, Donath A, Jühling F, Externbrink F, Florentz C, Fritzsch G, Pütz J, Middendorf M, Stadler PF (2013) MITOS: improved de novo metazoan mitochondrial genome annotation. Mol Phylogenet Evol 69(2): 313-319. https://doi.org/10.1016/j.ympev.2012.08.023 
27. Stothard P, Wishart DS (2005) Circular genome visualization and exploration using CGView. Bioinformatics 21(4): 537-539. https://doi.org/10.1093/bioinformatics/bti054

28. Sudhir K, Glen S, Li M, Christina K, Koichiro T (2018) MEGA X: molecular evolutionary genetics analysis across computing platforms. Mol Biol Evol 35(6): 1547-1549. https://doi.org/10.1093/molbev/msy096

29. Lewis DL, Farr CL, Kaguni LS (2010) Drosophila melanogaster mitochondrial DNA: completion of the nucleotide sequence and evolutionary comparisons. Insect Mol Biol 4(4): 263-278. https://doi.org/10.1111/j.1365-2583.1995.tb00032.x

30. Nardi F, Carapelli A, Dallai R, Frati F (2003) The mitochondrial genome of the olive fly Bactrocera oleae: two haplotypes from distant geographical locations. Insect Mol Biol 12(6): 605-611. https://doi.org/10.1046/j.1365-2583.2003.00445.x

31. Brujn MHLD (1983) Drosophila melanogaster mitochondrial DNA, a novel organization and genetic code. Nature 304(5923): 234-241. https://doi.org/10.1038/304234a0

32. Kim I, Lee EM, Seol KY, Yun EY, Jin BR (2010) The mitochondrial genome of the Korean hairstreak, Coreana raphaelis (Lepidoptera: Lycaenidae). Insect Mol Biol 15(2): 217-225. https://doi.org/10.1111/j.1365-2583.2006.00630.x

33. Coates BS, Sumerford DV, Hellmich RL, Lewis LC (2005) Partial mitochondrial genome sequences of Ostrinia nubilalis and Ostrinia furnicalis. Int J Biol Sci 1(1): 13-18. https://doi.org/10.7150/ijbs.1.13

34. Wang JP, Cao TW, Zhang Y, Fan RJ, Zhang M, Shi BM, Peng FC (2017) Sequencing and analysis of the complete mitochondrial genome of Limenitis helmanni (Lepidoptera: Nymphalidae). Acta Entomol Sin 60(8): 950-961. https://doi.org/10.16380/j.kcxb.2017.08.012

35. Li T, Yang J, Li Y, Cui Y, Xie Q, Bu W, Hillis D M (2016) A mitochondrial genome of Rhyparochromidae (Hemiptera: Heteroptera) and a comparative analysis of related mitochondrial genomes. Sci Rep 6: 35175. https://doi.org/10.1038/srep35175

36. Sun H, Zhao W, Lin R, Zhou Z, Huai W, Yao Y (2020) The conserved mitochondrial genome of the jewel beetle (Coleoptera: Buprestidae) and its phylogenetic implications for the suborder Polyphaga. Genomics 112(5): 3713-3721. https://doi.org/10.1016/j.ygeno.2020.04.026

37. Oliveira M, Lessinger AC (2005) Evolutionary and structural analysis of the cytochrome c oxidase subunit I (COI) gene from , and (Diptera: Muscidae) mitochondrial DNA. Mitochondrial DNA Part A 16(2): 156-160. https://doi.org/10.1080/10425170500039901

38. Yang F, Du YZ, Wang LP, Cao JM, Yu WW (2011) The complete mitochondrial genome of the leafminer Liriomyza sativae (Diptera: Agromyzidae): great difference in the A+T-rich region compared to Liriomyza trifolii. Gene 485(1): 7-15. https://doi.org/10.1016/j.gene.2011.05.030

39. Jin SB, Kim I, Sohn HD, Jin BR (2004) The mitochondrial genome of the firefly, Pyrocoelia rufa: complete DNA sequence, genome organization, and phylogenetic analysis with other insects. Mol Phylogenet Evol 32(3): 978-985. https://doi.org/10.1016/j.ympev.2004.03.009

40. Yue Z, Feng S, Zeng Y, Hong N, Liu L, Zhao Z, Fan J, Li Z (2018) The first complete mitochondrial genome of Bactrocera tsuneonis (Miyake) (Diptera: Tephritidae) by next-generation sequencing and its phylogenetic implications. Int J Biol Macromol 118(15): 1229-1237. https://doi.org/10.1016/j.ijbiomac.2018.06.099

41. Su Y, Zhang Y, Feng S, He J, Zhao Z, Bai Z, Liu L, Zhang R, Li Z (2017) The mitochondrial genome of the wolfberry fruit fly, Neoceratitis asiatica (Becker) (Diptera: Tephritidae) and the phylogeny of Neoceratitis Hendel genus. Sci Rep 7(1): 16612. https://doi.org/10.1038/s41598-017-16929-7 
42. Zhang DX, Hewitt GM (1997) Insect mitochondrial control region: a review of its structure, evolution and usefulness in evolutionary studies. Biochem Syst Ecol 25(2): 99-120. https://doi.org/10.1016/S0305-1978(96)00042-7

43. Brian MW, Michelle DT, Isaac SW, Norman BB, Jung-Wook K, Christine L, Matthew AB, Brian KC, Keith MB, Alysha MH, Benjamin MW, Kevin JP, Thomas P, Bradley JS, Jeffrey HS, Vladimir B, Jason C, Sujatha NK, Urs S-O, Gail EK, F Christian T, David AG, Andrew TB, Gregory WC, Markus F, Rudolf M, David KY (2011) Episodic radiations in the fly tree of life. PNAS 108(14): 5690-5695. https://doi.org/10.1073/pnas.1012675108 